\title{
Is mathematics created or discovered? Pre-service teachers' perception on a classic enigma
}

\author{
Vita Istihapsari1,2*, Rochmad², Isnarto² \\ 1Universitas Ahmad Dahlan, Jl. Ahmad Yani, Tamanan, Bantul, DIY 55191 Indonesia \\ ${ }^{2}$ Semarang State University, Jl. Kelud Utara III, Semarang 50237 Indonesia \\ ${ }^{*}$ Corresponding e-mail: vita.istihapsari@pmat.uad.ac.id
}

\begin{abstract}
There are many classic questions about the nature of mathematics which have been an endless debate among philosophers. One of them is about whether mathematics is created or discovered. This research aims to find out the pre-service mathematics teachers' perception about the classical enigma of mathematics after joining the course of history and philosophy of mathematics education. It was a descriptive qualitative research involving 45 pre-service mathematics teachers in their first-year training. We collected the data using questionnaire and then deepened the findings using semistructured interview. The results suggest that $40 \%$ of the respondents believed that mathematics is created, while the rest $60 \%$ believed that mathematics is discovered. The two claims have their basic reasoning in the perspective of the respondents. Those who believed that mathematics is created argued that mathematics exists because of human activities. Therefore, it will never be founded if it is not created first. Meanwhile, those who believed that mathematics is discovered tended to argue that whether or not there is human activities to prove the mathematics phenomena, it is already there as the God created it. Thus, human just discovered it, not create it. Both arguments are interesting and have a potential impact to the mathematics education practice.
\end{abstract}

Keywords: classic enigma of mathematics, philosophy, pre-service teacher

How to cite: Istihapsari, V., Rochmad, \& Isnarto. (2021). Is mathematics created or discovered? Pre-service teachers' perception on a classic enigma. International Journal on Education Insight, 2(1), 23-28. DOI: 10.12928/ijei.v2i1.4419

\section{INTRODUCTION}

Many experts define mathematics in several definitions or terms. One of them is a mathematical term derived from the Greek word written "mathein" or "mathenein" which means "to study" (Suyitno, 2014). However, the exact term or definition of mathematics cannot be applied with certainty and brevity. Definitions and mathematical terms are increasingly challenging because the branches of mathematics are increasing and getting mixed up with each other (Simamora, 2014). Mathematics is known as a universal science that underlies the development of science and technology, has an important role in various other fields of science to advance the power of human thought.

Mathematics is seen as an exact science since thousands of years ago. Many scientists whose work has survived thousands of years are not questioned, for example, Euclid's Elements, Newton's Principia, and Spinoza's Ethics (Ernest, 1991). However, in the end, the knowledge that is considered certain is questioned and successfully developed. The geometric system written by Euclid was questioned by contemporary scientists and gave birth to nonEuclidean geometric systems with the difference in the fifth postulate of parallelism (Prabowo, 2009) and Newton's view which was considered final in 
his day and was successfully redeveloped. This view raises the fundamental question of whether mathematical knowledge is definite.

In the philosophy of mathematics, two paradigms look at the truth of mathematics, namely the absolutist paradigm and the fallibilist paradigm. The absolutist view holds that the truth of mathematics is certain, that mathematics is the only knowledge that is certain, unquestionable, and objective (Ernest, 1991). This view is in line with the opinion of White-Fredette (2010), which states that the absolutist view views mathematics as a divine gift that never has errors or contradictions.

While the fallibilist view holds that mathematical truths can be corrected and will never be considered truths that will never be revised or corrected, this is reinforced by Hudson (2020), which states that fallibilists view mathematics as a human construction. Therefore it is prone to falsifiability (the possibility that a statement can be proven wrong through observation or physical testing) like human efforts. This absolutist view and fallibilist view are believed to influence the practice of learning mathematics.

The existence of mathematics teachers is an important key to the success of mathematics education in Indonesia (Abdullah, 2015). As a prospective mathematics teacher, one should have confidence in mastering mathematical knowledge (Sumartini, 2020). Of course, the mastery of mathematical knowledge as a prospective teacher is not only pedagogy but also knowledge of the philosophy of mathematics. It is stated in the curriculum of the UAD mathematics education study program, which states that prospective mathematics teachers can review information to determine the best choice as a basis for decision-making in solving problems. This provision is one of the basics for prospective mathematics teachers to study the philosophy of mathematics so that their confidence in mastering mathematical knowledge becomes optimal.

The arguments about mathematics up to now can be used as a puzzle that will trigger someone's thinking. Some of the classic puzzles proposed by Hers (1997) are: 1) whether mathematics was created or discovered; 2) finite or infinite mathematics; 4) mathematics is an object or process, and 4) mathematics changes or does not change. Hers (1997) reveals that in answering these riddles, no one can be blamed or justified, depending on the context or perspective of the philosophers.

With the classical puzzles about mathematics initiated by Hers, this study will reveal the perceptions of prospective mathematics teachers regarding these classic puzzles, especially in the first mathematical puzzle, namely mathematics was created or discovered. It aims to find out other views of prospective mathematics teachers on classical mathematics puzzles.

\section{RESEARCH METHOD}

This research is a descriptive qualitative research. This research was conducted in the mathematics education study program at Ahmad Dahlan University. The subjects of this study were 45 second-semester students. The subject was chosen at this level because students in the second semester are taking the History and Philosophy of Mathematics Education course. Thus, it will provide experience in the form of ideas related to classical mathematical puzzles that will be given. The data collection method used in this research is by using questionnaires and interviews. This research was conducted online because the conditions were still in the pandemic period, and lectures from the beginning were not face-to-face. Data collection in the form of a questionnaire was carried out using a google form. While the interview was conducted using WhatsApp.

IJEI, Vol. 2, No. 1, April 2021, 23-28 


\section{RESULTS AND DISCUSSION}

Giving questionnaires to 45 students of mathematics education study program, obtained 18 or as many as $40 \%$ of students think that mathematics was created, while 27 or $60 \%$ others think that mathematics was discovered. The results of the questionnaire can be seen in Figure 1.

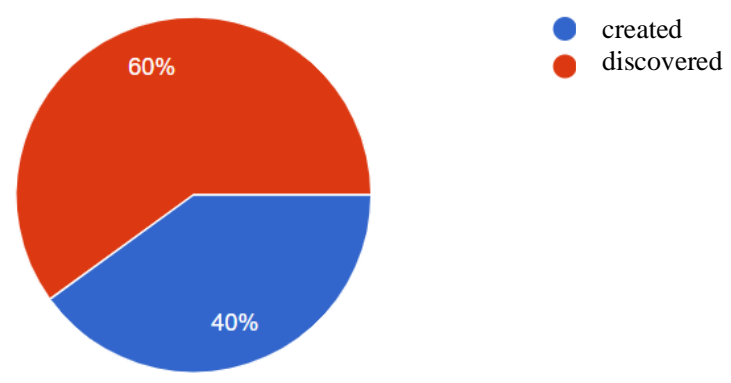

Figure 1. The results of the questionnaire whether mathematics is created or discovered

Based on Figure 1, it can be said that more students' views say that mathematics was discovered than mathematics was created. The questionnaire was continued by asking for an explanation from the opinions of all students. The summary of opinions from all students can be seen in Table 1.

Table 1. Students' opinions summary between MC and MD

\begin{tabular}{ll}
\hline Mathematics is & \multicolumn{1}{c}{ Opinion } \\
\hline created & 1. $\begin{array}{l}\text { Mathematics is seen as a science of arithmetic. The } \\
\text { existing calculations nowadays are the results of } \\
\text { scientists' creation, so mathematics is created. }\end{array}$ \\
& 2. $\begin{array}{l}\text { Mathematics is always used to meet human needs, } \\
\text { so it is necessary to create a science that studies } \\
\text { measurement, structure, logic, and others. }\end{array}$ \\
3. $\begin{array}{l}\text { Mathematics is a creation of logic, then simplified in } \\
\text { the form of language/symbols. }\end{array}$ \\
4. The truth of mathematics is derived from a \\
definition that cannot be confirmed. In other words, \\
the truth of mathematics is absolute, so that it is \\
seen that mathematics has a creator, namely God. \\
1. Mathematical formulas were discovered by \\
scientists, so that mathematics is said to be \\
discovered. \\
(MD) $\begin{array}{l}\text { Mathematics was discovered, the fruit of natural } \\
\text { observations that gave rise to certain patterns so } \\
\text { that an agreement was found from experts to } \\
\text { facilitate and meet human needs. }\end{array}$ \\
3. Until now, mathematics has always been discovered \\
or the result of the development of previous rules. \\
4. Everything in this world is God's creation, so \\
scientists only discover what already exists.
\end{tabular}


After the questionnaire is completed, interviews will be conducted with four students who think mathematics was created and four students who think that mathematics was discovered. Excerpts from interviews with students who think that mathematics was created are as follows.

Researcher : "Why do you think that mathematics was created? Explain!"

Subject 1 : "Yes, ma'am, because the formulas in mathematics were created by scientists, ma'am. All mathematical calculations are scientists who create it."

Subject 2 : "Besides that, ma'am, humans also need mathematics to measure, predict, or think of something new for other sciences, ma'am."

Researcher: "Ok, how about you? What do you think?"

Subject 3 : "I am almost the same as other friends, ma'am, so humans will use logic or their minds to create something in mathematics, then the results of their creation will change in the form of symbols or symbols or other languages to make it easier for humans to communicate."

Researcher: "Yes, good, lastly, what do you think?"

Subject 4 : "I believe that mathematics is the one who created God, Ma'am, and what I have studied states that the truth of mathematics is absolute so that mathematics was created, Ma'am. For example, a point, that point already exists in this world and was created by God. It is just that humans represent a point in the form of a very small circle."

Researcher: "I see, so if mathematics was created by God, it means that it can be said that mathematics was only discovered by humans through experiments or human experience, because everything already exists in this world, humans just need to find it?"

Subject 4 : "Uhm, yes, it could be the same thing, Ma'am. I also have a new view like that."

The following is an excerpt from interviews with four other subjects who argue that mathematics was discovered.

Researcher: "Why do you think that mathematics was discovered? Explain!"

Subject 5 : "In my opinion, mathematics was discovered because the current formulas were discovered by scientists, ma'am, not created."

Researcher: "Ok, anyone want to add the opinion of Subject 5?"

Subject 6 : "I am Ma'am, the formula that was found actually came from the observations of scientists, then usually it will form patterns so that later the formula that is agreed upon by other scientists is found, ma'am."

Researcher: "Well, try it (Subject 7). Why do you think mathematics was discovered?"

Subject 7 : "Actually, my opinion is almost the same, Madam, so I think that until now mathematics has been found from the development of pre-existing rules, for example, Euclid's geometric system, which was originally formed by logical deduction of theorems from axioms, then there are who can develop it on the fifth axiom so that it is claimed to be a non-Euclidean geometry."

Researcher: "Yes, that is good. Is there anything else you want to add?" 
Subject 8 : "I think Ma'am, everything in this world is God's creation. Mathematicians are actually just discovering what already exists, ma'am, so it was not created by humans."

Researcher: "Good, thank you all for the explanations given."

Based on Table 1 and the results of interviews, students who have a mathematical view are created. All mathematical components such as calculations, formulas, symbols, symbols are created by scientists. It means that the idea did not exist before the creator thought of it. Moreover, mathematics is universal science, meaning that mathematics is used in various other fields of science to meet the needs of human life so that scientists create innovations/new ideas using logic. From this new idea, symbols, language, formulas, etc., are created. In addition, mathematics is seen as God's creation so that it contains absolute truth. Students' opinions about mathematics being created are in line with formalists and intuitions, which state that mathematics cannot be found because nothing can be found before someone made it in this world (Hers, 1997).

Students who have a mathematical view are found to think that mathematical formulas are not created by experts but are findings from the results of their experiments. It means that a scientist, especially a mathematical scientist, will find various patterns from natural observations to find agreements to meet human needs. Until now, mathematics continues to produce findings from the results of the development of previous rules. When someone is faced with a problem-solving problem, of course, the solution to the problem is found, not created. So that it can be said that one experiences a problem in this world, they will find solutions, not create solutions. Only God created everything in this world, including science, so scientists only discover what already exists.

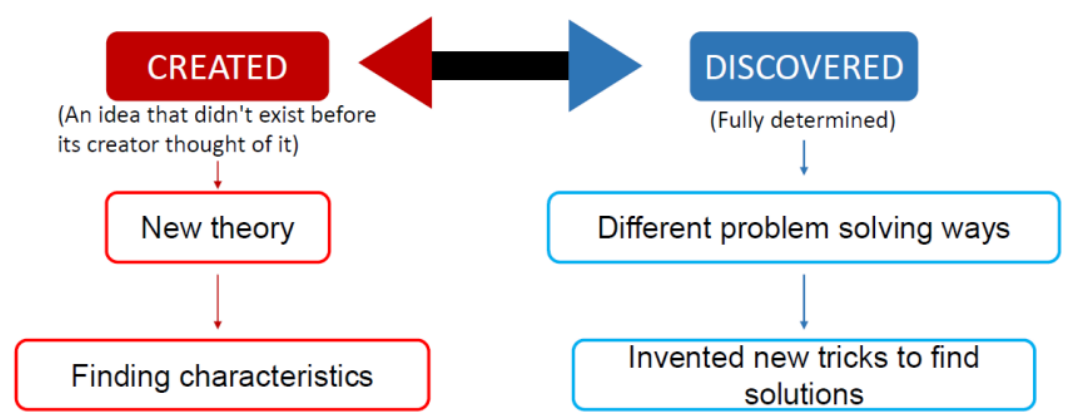

Figure 2. Views about mathematics created or discovered

A clarification about whether mathematics was created or mathematics was discovered can be seen in Figure 2. There is a slice of view about mathematics created or mathematics found from the opinions of students above. Students who claim that mathematics was created (MC) argue that mathematics comes from ideas that never existed before its creator/mathematical scientist thought of it. However, as knowledge and technology develop, scientists will continue to create new theories until they find their properties or characteristics with the correct formulas. Of course, the exact formula cannot be obtained directly, but through a series of experiments that are said by students who view mathematics as found (MD). These various experiments will find the characteristics or properties of the theories created by 
scientists. So it can be said that the theory created by scientists leads to findings in the form of traits or characteristics. It is in line with Siskawati's (2021) statement that the difference between created and discovered is the difference between two types of mathematical progress. So, was mathematics created or discovered? The answer is both because progressive mathematics will require both.

\section{CONCLUSION}

The two claims, whether mathematics is created or discovered, have their basic reasoning in the perspective of the respondents. Those who believed that mathematics is created argued that mathematics exists because of human activities. Therefore, it will never be founded if it is not created first. Meanwhile, those who believed that mathematics is discovered tended to argue that whether or not there is human activities to prove the mathematics phenomena, it is already there as the God created it. Thus, human just discovered it, not create it. Both arguments are interesting and have a potential impact to the mathematics education practice.

\section{REFERENCES}

Abdullah, S. S. (2015). Mahasiswa (calon) guru matematika yang profesional. Seminar Nasional Matematika dan Pendidikan Matematika UNY (vol. 1, pp. 721-726). Yogyakarta: Universitas Negeri Yogyakarta.

Ernest, P. (1991). The Philosophy of Mathematics Education. Routledge: Taylor and Francis.

Hersh, R. (1997). What is Mathematics, Really? New York: Oxford University Press.

Hudson, R. A., Creager, M. A., Burgess, A., \& Gerber, A. (2020). The nature of mathematics and its impact on K-12 education. Critical Questions in STEM Education (pp. 45-57). Springer, Cham.

Prabowo, A. (2009). Postulat kesejajaran Euclid dalam tinjauan sejarah. Jurnal Ilmiah Matematika dan Pendidikan Matematika, 1(2), 67-91.

Simamora, L. (2015). Pengaruh persepsi tentang kompetensi pedagogik guru dan kebiasaan belajar siswa terhadap prestasi belajar matematika. Formatif: Jurnal Imiah Pendidikan MIPA, 4(1).

Siskawati, E., Rochmad, R., \& Isnarto, I. (2021). Teka-teki klasik filsafat matematika. PRISMA, Prosiding Seminar Nasional Matematika (vol. 4, pp. 189-193).

Sumartini, T. S. (2020). Self-efficacy calon guru matematika. Mosharafa: Jurnal Pendidikan Matematika, 9(3), 419-428.

Suyitno, H. (2014). Pengantar Filsafat Matematika. Semarang: Penerbit FMIPA Universitas Negeri Semarang.

White-Fredette, K. (2010). Why not philosophy? Problematizing the philosophy of mathematics in a time of curriculum reform. The Mathematics Educator, 19(2), 21-31. 